\title{
Devolving the Power to Divide: Sectarian Relations in Egypt (2011-12)
}

\author{
Mariz Tadros
}

Abstract This article is about decentralisation and social cohesion in religiously heterogeneous communities in times of political transition. Post-Mubarak Egypt is taken as a case study involving the informal devolution of power in managing sectarian relations between the majority Muslim and minority Christian populations between February 2011 and June 2012. On the surface, the process had features of a political decentralisation of power which holds promise of downward accountability. The Supreme Council of the Armed Forces (SCAF) delegated the governance of local sectarian conflict to religious community leaders enjoying high popularity, a policy that was subsequently followed by the Muslim Brotherhood-led government. However, the process of local leaders assuming the power to govern was also an unintended consequence of the collapse of rule of law in a context of extreme political volatility associated with a country in revolt.

\section{Introduction}

The article argues that sometimes devolution of power can lead to the enforcement of majoritarian democracy which is exclusionary towards minorities, undermines social cohesion and increases sectarian violence against minorities, rather than create space for voice and accountability. In other words, what may seem on the surface as democratic decentralisation may under certain conditions be a devolution of power to local leaders who contribute to the persecution of minorities, even if they are supported by a great proportion of the local residents. Social cohesion is chosen as an analytical category because it allows for an examination of changing social relations in terms of times of extraordinary political change as in the case of Egypt, 2011-12. The examination of sectarianism against the backdrop of processes of devolution of political power provides empirical data to test the assumed positive relationship between decentralisation and social cohesion highlighted in much of the scholarly literature reviewed in Section 2.

The second section of the article discusses the concepts of social cohesion, decentralisation and power as they apply to this context - Egypt's transition - and provides analysis as to the causes and manifestations of increased sectarianism as they have featured in the period
2011-12. A case study of conflict mediation through informal justice mechanisms is taken to show the conundrums of informal devolution of power to local leaders who are not accountable to anyone, in the absence of the effective implementation of rule of law. Informal justice mediation is chosen on several accounts for the following reasons.

First, theoretically, the administration of justice through informal local mediation as opposed to the formal recourse to justice has been one of the key dimensions associated positively with political decentralisation processes. Hence the empirical data provided by the Egypt case study was useful in exploring the relationship between informal justice mediation (as one of the proxies of decentralisation) and sectarian relations (as an aspect of social cohesion). Second, in view of the emerging pattern of informal justice committees being led and mediated by popular Islamist leaders after sectarian acts of violence, this seemed to be an important dimension of the new configuration of power. Third, in these incidents there were clear processes of devolution of power from the centre to the local religious leaders, which allowed for a consistent documentation of the actors, agendas and outcomes. Fourth, these processes of informal justice mediation became widely publicised in 
Egypt, allowing for a useful examination of the interface between the local and the national, and how they affect each other.

\section{Decentralisation, social cohesion and power}

There is a burgeoning literature suggesting that one of the measures that can promote social cohesion and deal with religious and ethnic conflict is decentralisation. Brief definitions of the concepts as they are deployed here are needed. Social cohesion is a 'fuzzword' that can have multiple meanings. Norton and De Haan (2012: 4) define social cohesion as 'the capacity of societies and social groups to peacefully and inclusively navigate social change, while enhancing individual and group rights and freedoms.' They argue that in practical policy terms, this requires (1) accounting for low levels of social exclusion, (2) empowerment of minority and disadvantaged groups, (3) promoting low levels of violence, and (4) strengthening institutions for peaceful management of rapid change. This approach benefits from the social dynamics approach developed by Marc et al. (2013), but is more comprehensive because it (1) creates a greater balance between a societal approach and a statist approach, (2) makes the notion of inclusive policies and rights more explicit and central and (3) recognises the need for dealing with inequalities as well as forging collective identities.

Norton and De Haan (2012: 4) warned that for the concept of social cohesion to be useful for the purposes of designing policy to support progressive developmental change, it needs to avoid 'a bias to the established social and political order and a bias to cultural and social homogeneity' (italics in original). If power hierarchies between groups are ignored, then the bid for creating solidarity can mean a re-enforcement of existing hegemonic normative frameworks based on the beliefs and ideas of the majority. The focus on creating social harmony and solidarity in the concept of social cohesion may lead, in more extreme cases, to an emphasis on participation of people, irrespective of whether they are participating out of a sense of inclusion or whether their participation is forced or for performance purposes. For example, Chan, To and Chan (2006: 284) argue that 'social cohesion requires only people's participation, cooperation and mutual help; as such it does not presuppose values like tolerance or respect for diversity, or vice versa.' This kind of understanding of social cohesion when using proxies such as participation without looking at power relations says nothing about the quality of social relations existing between those cooperating and therefore says nothing about whether a society is cohesive or not.

Decentralisation here refers to the transfer of political and/or economic decision-making powers from central to local government. Tranchant suggested that the devolution of power from the centre to the groups that have been marginalised reduces their vulnerability to discrimination and increases their sense of control over their own affairs: 'In the field of ethnic conflict, it is supposed to dampen strife by giving groups control over their own affairs and by insulating minorities from predatory politics from the centre' (Tranchant 2007: 13). The implicit assumption here of course is that the conflict is occurring between groups that occupy different parts of the country; hence the devolution of power would go to those groups in the periphery. Tranchant did not address the problem that such devolution of power may re-enforce unequal power hierarchies between the majority and minority on a local level.

Kaplan (2009: 471) contended that one of the advantages of decentralisation in relation to social cohesion is that it grants the ruling powers legitimacy in the eyes of the people:

a shift from state-centric to more local level governance would enhance the legitimacy of the political order... Whereas a robust state uses local identities, local capacities, and local institutions to promote its development, a fragile state's formal governing structures undermine all of these indigenous assets. As a consequence, a weak state cannot leverage its people's histories and customs to construct effective formal institutions with wide legitimacy; nor can it draw on the social capital embedded in cohesive groups to facilitate economic, political, and social intercourse; and nor is it able to employ the traditional governing capacities of its citizens to run the affairs of state.

Following the same line of argument, Marc et al. (2013: 189) pointed to another way in which decentralisation affects social cohesion.

Devolution of power that empowers institutions 
that operate locally can provide a space for groups to participate in their own development space that might not exist at the central level.

He affirmed that 'community driven

development if acting as a function of local governance, can reduce patronage and elite capture if well designed' (ibid.). However, the same study warned that community-driven development might not necessarily lead to social cohesion if 'projectivised' and if it ignores contextual dynamics. Local governance measures proposed in the study by Marc $e t$ al.(2013) to support social cohesion include supporting informal justice mechanisms (local forms of addressing conflict; for example, through customary laws and practices); the promotion of participation in local structures including service delivery; and the encouragement of civil society to create bridges across groups. While these measures in and of themselves may have potential to be effective in certain contexts, what will be argued through the Egyptian case study, is that they can also be used to re-enforce unequal hierarchies.

Efforts to foster solidarity across advantaged and disadvantaged groups can come at a cost: ignoring the underlying structural roots of inequality, and accordingly not adopting policies that deal with them. As Dixon et al. (2002: 417) have suggested:

Research on common identification suggests that even when we are successful in creating more positive intergroup attitudes, encouraging people to evaluate one another more favourably, we may leave unaltered the conservative policy orientations of the historically advantaged. Viewing others as part of a shared in-group, it seems, does not necessarily promote support change in a structural or institutional sense. Moreover, members of dominant groups lean towards 'assimilative' forms of inclusion that preserve rather than challenge social inequalities.

A power analysis may expose how devolution of power to manage local conflict may seem on the surface as enhancing local citizen participation, but when occurring in conjunction with other political phenomena may perpetuate inequalities. For example, hidden power characterised by who sets the agenda and the terms of engagement, what is to be kept off the agenda, who is invited, and who is kept out, determines the nature of relationships being forged under the 'social cohesion' mantra. If both groups have been raised to believe that it is natural/expedient for the stronger party to influence and shape the agenda, then through the invisible power of these normative values, such an assimilative form of intergroup collaboration is presented as a step towards social cohesion.

Visible power refers here to:

seeing who participates, who wins and who loses in these arenas... For instance, we can analyse which interests are able to maintain debate, whose interests prevail in key decisions, such as on a key policy or budget decision, and whose voices and interests are present, but have little influence. ${ }^{1}$

One of the limitations of focusing exclusively on visible ways in which power is exercised is that there is little attention being paid to those voices that are not being represented and the reasons behind it.

\section{Hidden forms of power:}

are used by vested interests to maintain their power and privilege by creating barriers to participation, by excluding key issues from the public arena, or by controlling politics 'backstage'. They may occur not only within political processes, but in organizational and other group contexts as well, such as workplaces, NGOs or community-based organizations. ${ }^{2}$

Invisible power goes a step further than hidden power because it does not look at the issues that are kept off the agenda, but the ways in which ideologies, values and forms of behaviour influence how people think and relate to issues.

In this form of power, people may be unaware of their rights, their ability to speak out, and may come to see various forms of power or domination over them as 'natural', or at least unchangeable, and therefore unquestioned. Poor people, for instance, may accept their circumstance as the status quo even in the face of inequalities around them, internalizing dominant explanations of poverty. ${ }^{3}$ 
These three concepts inform the power lens used to examine decentralisation and social cohesion in the context of Egypt's transition in the next section.

\section{The Egyptian context}

Mubarak, who ruled Egypt for almost 30 years, was ousted on 11 February 2011, against the backdrop of mass citizen uprisings and some army commanders' allying with the people in a quiet coup against the president (Tadros 2012a). The 18 days of uprising witnessed a historical moment of citizens unifying under a common cry: 'Bread, Freedom, Social Justice' (a variation of which was 'Bread, Freedom and Human Dignity). In Tahrir Square, in particular, what emerged was a space with its own normative social values that was distinct from the rest of the country. Images of men holding the Koran and the cross were widely disseminated in the media, intended to enforce the notion that there is religious unity in the face of a common oppressor.

Yet the spirit of Tahrir Square did not have a ripple effect spatially or temporally on Muslim-Christian relations after the common mission of ousting Mubarak had been accomplished.

\section{The Supreme Council of the Armed Forces} (SCAF) which assumed power after the ousting of Mubarak in 2011 forged an informal alliance with the Muslim Brotherhood (Tadros 2012b).

The incidents of sectarian violence against Christian minorities, Baha'is and Sufis increased in $2011 .^{4}$ This rise in sectarian violence has its historical roots in a complex set of factors including state policies that were discriminatory against Christian minorities; the Islamisation from below by the Muslim Brotherhood, the Salafis and a plethora of Islamist movements; rising intolerance towards religious minorities and bad governance more broadly. However, the state security investigations (SSI) apparatus used tactics of both repression and appeasement to control the sectarian situation on the ground. In the aftermath of the January 25th revolution, the SSI apparatus [mabah amn al dawla] temporarily took back stage and no longer governed sectarian relations - at least not visibly. As draconian measures on the regulation of political space were lifted, civil and uncivil forms and expressions of political agency were unleashed. Sectarian animosity towards Christians which had been simmering under the surface - but was muted by the security apparatus - came to the surface after 25 January. The complete breakdown of a functioning security system (in the sense of protecting citizens from individual and organised forms of violence and crime) and absence of rule of law affected all Egyptian citizens, but made Coptic citizens particularly vulnerable to violence.

However, the rise in sectarianism was not only a consequence of cumulative build-up of sectarian violence of previous years and security breakdown in the aftermath of a revolution, it was also a direct consequence of the policies pursued by the army (SCAF) when it ruled the country between February 2011 to June 2012 and further amplified after President Morsi took over. The military police were responsible for the single worst incident of sectarian violence against Christians in contemporary Egyptian history. On 9 October 2011, thousands of protesters had staged a peaceful march to the national state broadcasting station known as the Maspiro building in downtown Cairo to condemn the burning of a church by extremists in the governorate of Aswan. They were then attacked by security forces and the army's military police, the latter using army vehicles that looked like tanks to repeatedly run over fleeing protesters. The assault which became known as the Maspiro massacre, was captured on live TV and broadcast worldwide, led to 28 deaths and an estimated 200-300 injuries. Hamdeen Badin, the Chief of the Army Police who gave the orders for the army police to attack the protesters was a member of SCAF and to date has not been prosecuted.

Against the backdrop of a hostile political stance on the part of SCAF towards religious minorities, the new power configuration in Egypt had bestowed on the Muslim Brotherhood and the Islamists more generally substantial formal and informal power to influence all levels of governance. This had a direct relationship on sectarianism relations, a theme I return to later.

Table 1 comprises incidents recorded in the press between 2008 and 2012 compiled and verified by author.

\section{Triggers of sectarian conflict}

In order to trace the changing pattern of sectarian assaults over time and to show how levels of violence featured before and after the 


\begin{tabular}{|c|c|c|c|c|c|c|c|}
\hline & 2008 & 2009 & 2010 & 2011 & 2012 & Total & $\%$ \\
\hline Escalation of small disputes/fights & 11 & 14 & 1 & 11 & 24 & 61 & 20.89 \\
\hline $\begin{array}{l}\text { Building/expansion of churches or related to its } \\
\text { registration/licence }\end{array}$ & 1 & 8 & 10 & 15 & 12 & 46 & 15.75 \\
\hline $\begin{array}{l}\text { Muslim/Christian gender relations and } \\
\text { disappearance of women and girls* }\end{array}$ & 4 & 7 & 9 & 13 & 13 & 46 & 15.75 \\
\hline Reasons related to Coptic converts to Islam & 3 & 0 & 13 & 6 & 7 & 29 & 9.93 \\
\hline Property disputes & 7 & 2 & 3 & 3 & 5 & 20 & 6.85 \\
\hline Attacks on Christian protesters & 0 & 0 & 1 & 4 & 0 & 5 & 1.71 \\
\hline News/rumours of defamation of Islam & 2 & 0 & 1 & 1 & 7 & 11 & 3.77 \\
\hline Alleged Christian evangelical activities & 1 & 0 & 2 & 0 & 0 & 3 & 1.03 \\
\hline Other reasons & 4 & 1 & 2 & 1 & 4 & 12 & 4.11 \\
\hline Untriggered - no reason & 0 & 0 & 3 & 16 & 40 & 59 & 20.21 \\
\hline Total number of incidents & 33 & 32 & 45 & 70 & 112 & 292 & 100.00 \\
\hline
\end{tabular}

Note ${ }^{*}$ Italics were not applied to the original analysis for 2008-10 but were added thereafter as a consequence of the widening scope of the nature of the trigger.

Source Author's own (analysed further in Tadros 2013).

January 2011 revolution, an analysis of incidents was captured from 2008 to 2012. (It was not possible to acquire the data for the years prior to 2008 and data for 2013 is still being synthesised). An analysis of the data for 2008-12 shows that not only have the number of sectarian incidents increased since 2011 in quantitative terms, but qualitatively, the level of intensity of assault has also increased. It is possible to note the following number of indicators of increasing violence against Christian minorities, the first being the transformation of small-scale disputes that are not of a religious nature into collective assaults on minority groups if one party in the dispute happens to be Christian. A most common trigger is rumours spread about a Christian acting in a way that is offensive to his/her fellow Muslims, such as allegedly slandering religion or about an individual verbally or physically attacking a Muslim (i.e. that s/he allegedly slandered Islam). A dispute between children in a street football match, where one party happens to be a Christian can lead to the mass mobilisation of Muslims in the neighbourhood (and sometimes adjoining ones) to collectively avenge for the Muslim who has been wronged by the Christian. Such avenge does not happen against the Christian in question, but his family and
Christians in the surrounding area, even if they were completely unrelated to the incident.

The second trigger (and cause) of sectarian violence is associated with the construction and renovation of Christian places of worship.

Following the revolution, a new phenomenon emerged which makes it difficult to classify as 'church expansion/construction related'. These were acts which did not involve either the construction or renovation of churches, nor were brought about by any visible triggers. Such acts included the Salafi occupation and attempted annexation of church-owned buildings, the mobilisation of citizenry to press that a church be closed on the premise that it is unlicensed, or acts of sudden destruction of church fences and annexation of parts of the premises (all of which occurred in Minya, Cairo, Beni Suef, Sohag, for example). This shows a rather serious new development, in incidents of 'untriggered' assault on Coptic Christians. It suggests that there has been a rise in the level of intolerance, such that the very existence of churches in an area is cause for sectarian assault.

The third main trigger of sectarian assault was matters to do with Muslim-Christian gender 
relations which are considered anathema for the majority if they involve a Christian man being in a relationship with a Muslim woman and anathema for a minority if they involve a Muslim man in relationship with a Christian woman. What causes sectarian strife is often when Christian women disappear and their families discover that they have converted and married a Muslim man, but they have no way of finding out whether they did so voluntarily or under pressure. Matters become particularly aggravated when the missing daughters are minors (below 16 years of age), in which case legally they are under the guardianship of their families and the state is obliged to help them find their daughters, which it is reluctant to do.

However, after the revolution, once again, a new phenomenon emerged, making it difficult to classify under 'gender relations' and that is the disappearance of young girls and women (at least eight incidents in 2012) where there is no evidence that a relationship with a Muslim man existed previously. These were incidents in which women were out on errands or returning from a social engagement and never returned. In one instance, a Salafi leader admitted that the young woman, aged 14, was in their company, that she intended to convert and that the family should not try to get in touch with her. These incidents have led to the organisation of protests and marches by Coptic citizenry, sometimes entering into direct confrontations with the powers that be.

The most dramatic change in sectarian violence to have occurred after the Islamists informally rose to power in 2011 and formally assumed office in 2012 has been the rise of 'untriggered' incidents of assault against Christians. There were three such incidents in 2010, 16 in 2011 and 31 in 2012. For example, there were several incidents in which Coptic Christian women were assaulted for not wearing a veil. While non-veiled Muslim women were also exposed to such acts, in the case of the former, they would be accompanied by verbal abuse such as being referred to as 'infidels'.

What is clear is that the overwhelming majority of sectarian incidents of violence occur at the community level, rather than high-level confrontations between religious leaders or state figures at a national level. There was a political vacuum created once the SSI apparatus retreated from governing at local level, leading to the emergence of alternative actors who assumed a community policing role. This was not a state policy of decentralisation through legislation delegating responsibility to local authorities or formal institutions. It was a combination of rulers delegating local leaders with the responsibility of mediating sectarian relations but also a by-product of the collapse of the tight rein of the former regime on local spaces which became captured by new political actors. This new configuration of power was to have a central impact on the mediation of relations between Muslims and Christians at a local community level.

\section{Informal devolution in Egypt: ruptures in social cohesion}

The Muslim Brotherhood-led government that ruled between July 2012 and June 2013 did not take any formal measures of decentralisation such as delegating central government budgets and responsibilities to local municipalities and councils. The government has also not formally sought to devolve the power of central government to issue legislation at a local level. Nor have service delivery measures been implemented in a way to increase local ownership and management. However, there have been a number of informal mechanisms of decentralising authority to the benefit of local actors. There have also been incidents where the government had to yield to local demands associated with governance issues. In the following section we will examine instances of decentralisation through the pursuit of informal justice mechanisms in a context where security is lax (no policemen to protect civilians from violence) and there is no rule of law. The focus here on informal justice is also informed by local contextual dynamics: namely, how conflict is mediated wields important political signals to the broader community on the status quo's tolerance for violence against minorities and where the power lies in framing and determining what justice is.

\section{Devolution through the enforcement of informal justice mechanisms}

One of the most dramatic changes occurring after the revolution is in the shift in the management of sectarian incidents on a local level from the SSI apparatus to that of the Muslim Brotherhood and the Salafis. The outcome of such informal committees for 
administering justice has been the creation of deep fissures between Muslims and Christians in a way that severely undermines social cohesion.

A troubling phenomenon had started to appear from 2000 onwards (Shoukry 2009) which is that of informal reconciliation sessions as mechanisms of administering justice. These were in lieu of recourse to justice. In the Urfi (customary) justice system, the head of the tribe or elder reputed for being just and wise arbitrates after hearing the accounts of both parties. In view of their social legitimacy, decisions arrived at during these customary sessions are considered binding. Since the process is governed by the principles of Islamic Sharia, there are specific conditions to be met in the selection of the judge, the presence of witnesses, the presence of the defence, the people, the process of issuing a decree, and so forth. However, Shoukry (2009) noted that what occurred was the distortion of how Urfi courts were historically administered.

There was one major significant difference perhaps between the $U r f i$ courts as they were administered in tribes and Bedouin communities and as they have been administered in cases of sectarian violence: namely, the arbitrator became the SSI apparatus which was able to exercise soft power (persuasion and 'firm requests') and hard power (incarceration and threats of torture) should citizens not comply. Its powers had in many instances in Mubarak's Egypt surpassed those of the National Prosecutor and hence, it was empowered to usurp the course of justice through the administration of the rule of law. Ironically, it was a case in which the arbitrator of justice was an accomplice in the very act of violence that was instigated in the first place. In the majority of cases of SSIadministered incidents of reconciliation sessions (lejan al solh), there was a clear attempt at mollifying the dominant group in the community at the expense of the weaker party. The rulings often meant a collective penalisation of all the Christian inhabitants of a particular village as a consequence of the act of one individual or family, and it often meant that compensation for assaults made on Christian places of worship or property were, if at all, only of a nominal value.

As the political restrictions against civil activism waned after the revolution, the inhibitions against Islamist forces were removed, and they assumed a more prominent leadership role in public in particular on a local level. Yet replacing state security officials with local influential authoritative leaders who have large followings did not create the conditions for more social cohesion, but rather social alienation. What will be shown next is that the delegation of resolution of conflict to the Salafis with the implicit endorsement of the Muslim Brotherhood-led government did not deliver on justice any more than the SSI-mediated reconciliation sessions enacted during Mubarak's era. On the contrary, the outcome of these informal sessions was even greater injustice. Reconciliation committees, as they have been run, institutionalise the collective subjugation of a religious minority to the majority with severe implications: first, they re-enforce the power of the Salafis and the Muslim Brotherhood as the authoritative mediators of conflict; second, they signal the non-accountability of the mediators to a higher authority; third, they send political signals to communities that those who mobilise the citizenry to instigate violence against the minority will not be prosecuted; fourth, they generate long-standing animosity in the community that may in the long run be fertile ground for further violence.

The problem does not lie in the principle itself of bringing together the leaders who have authority and legitimacy in the community to mediate in conflict resolution, rather it is in the way in which it increases the power of leaders whose agenda and ideology is exclusionary towards the weaker party. In effect it may appease the crowds at that moment but it contributes to a disabling environment for nurturing social cohesion on a long-term basis.

In one of the first sectarian incidents under the reign of the SCAF, a church was burnt in the village of Sol in close vicinity to Greater Cairo and reconciliation sessions were held to deal with the crisis. A Christian man was caught alone in the company of a Muslim woman in his car, which stirred popular outrage and demands for the reclaiming of honour. Concurrently, rumours of a long-standing relationship between another Christian man and a Muslim woman suddenly surfaced. The elders of the most prominent families in the village met with the local priests and asked that the two Christian men in question be expelled from the community. The 
priests agreed, and believed this was a reasonable settlement that would hopefully secure peace and harmony in the village. This was the first of an informal, closed meeting to administer justice, which would have worked if the matter had stayed at the level of the individual families in question. However, matters associated with gender and honour are often difficult to contain, as extended family and tribes become involved. The uncle of the woman who was rumoured to be in a relationship with a Christian man confronted her father and pressed him to kill his daughter to cleanse the family honour. A dispute ensued between them, the father refused to kill his daughter and defended her virtue, the uncle insisted that the family honour had been tarnished, matters escalated, and both shot each other to death.

On 4 March 2012, the day of their burial, after Friday prayers, unknown persons incited citizens to seek vengeance against the Christians who were blamed for the loss of the lives of the two Muslim men. The uncle was a member of the Islamist movement (the author is unclear whether this was the Salafis or the Muslim Brotherhood). Inhabitants of Atfeeh responded by burning the church and looting and pillaging the property of many Christian residents of the area. In the first reconciliation session that was held soon after with SCAF's presence and with the participation of the Muslim Brotherhood and Salafi leaders, and representatives from the church, the church leaders were pressed to agree to rebuild the church in a different location, preferably on the edge of town, to avoid disturbing majority sensibilities. It was also agreed that the perpetrators (who were caught on camera) would not be tried. ${ }^{5}$ This was the first administration of informal justice in which the Islamists were brought in to mediate. The terms of the agreement were in some ways similar to those of the security apparatus, and in some ways much worse. In such cases the SSI would have pressed on a settlement that does not include referring the perpetrators to trial. While there have not been instances in which a church was attacked during Mubarak's reign, there are no records of the SSI ruling in the informal sessions that it be relocated outside the village. In other words, the level of injustice imposed was even higher.

Following massive protests led by youth coalitions and Copts at Maspero, the army volunteered to rebuild the church, although the perpetrators were never referred to trial. When the army came under open fire for having summoned the renowned Salafi Sheikh Mohammed Hassan (commonly known as Sheikh Hassan) to manage the reconciliation committee, SCAF sought to deflect criticism of their continued reliance upon him for managing sectarian strife by explaining that it is 'because people listen to him. ${ }^{6}$ The army built a new church in a speedy and efficient manner, and they also built a new mosque, of great grandeur and of greater proportions to the church in the same village, in addition to building a new bakery and upgrading the existing health centre.

The Coptic families that left following the crisis returned but one of the Coptic residents who was interviewed a year later, reported that though there have been no outbreaks of violence, the situation has remained tense. One man said 'now if there is a wedding or a funeral, we don't go to pay our tribute and likewise they don't come to ours [weddings and funerals] except those who are very close friends'. The same man was keen to point out that some Muslims played an exceptionally heroic role in trying to protect the church and the homes of the Copts from being looted and plundered; however, things were not like they were before. 'It's like each keeps to his own' said another interviewee. What the above suggests is that while informal reconciliation sessions mediated by popular local leaders may end the crisis, the non-enforcement of justice creates a deep rupture in social relations which lingers on, well after the incident itself.

Members of the Muslim Brotherhood and the Salafis also organised a series of widely publicised reconciliation committees in the village of Al Nahdah in the town of Ameriyya, Alexandria in January/February 2012. In January 2012, rumours spread that a Christian man had allegedly circulated indecent images of a Muslim woman via his mobile. Out of fear for his life and the lives of his family, the young man in question gave himself up in the local police station but the village youth congregated and demanded that his family be expelled as well. This was followed by acts of burning and vandalism of homes and property owned by Copts. In one instance, a member of one of these families fearing for his life against the crowds shot bullets in the air. Three reconciliation committee meetings led by 
the Salafis and the Muslim Brotherhood were convened to deal with the matter. The reconciliation committees were attended by Lieutenant (Ameed) Khaled Shalaby, a security personnel, but led by the Salafi sheikhs, headed by Sheikh El Sherif el Hawary. In the first reconciliation committee meeting, despite the expressed opposition of the local priest and the Coptic family in question to the clauses of the agreement, it was decided that three families would be expelled, and that a committee would be formed to sell their property. However, the youth congregated felt that this was insufficient punishment. In reaction, a second reconciliation committee meeting was convened and it was agreed that five more Coptic families would be added to the list of those to be expelled (Gad 2012).

In the third conclusive reconciliation committee meeting, eight other Christian families who had nothing to do with the young man were forcibly expelled from the village. The agreement clauses published in Al-Wafd newspaper stipulated that on 1 February 2012 the 'exit' of the families was for the protection of their lives. One of the more interesting clauses was bestowing upon the committee the responsibility of selling the properties belonging to the expelled families, with the pricing and the process of selling and buying to happen under the direction of Sheikh El Sherif el Hawary. What is striking is the way in which the right to dispense with the property of the Christian families, one of whom was known to be one of the wealthier members of the village, was violated. The Salafi and Muslim Brotherhood leaders in the reconciliation committee usurped the right of the police to investigate and prosecute, and yet this contract was signed in the presence of the highest security authorities in Alexandria.

The second interesting clause was to bestow upon the arbitrators the responsibility of determining the scope of damage 'in accordance with the precepts of the Sharia' (Oreiby 2012). The reference to the Sharia law is interesting because reconciliation committees have conventionally followed a number of social customs and traditions, which have geographically differed from one area to the next. The urf, or custom, in this area was that a man would not be expelled except if there was a case of premeditated murder, and even then, he himself would depart, but not his family. As for the punishment for shooting bullets in the air with the intention of scaring people off, custom has it that the person would apologise and compensate any victims injured. The collective punishment of the Copts and their expulsion was contrary to local custom (Gad 2012).

Once again, the press and media leaked the details of the agreement, forcing parliament to intervene, which sent a committee to investigate the matter and press for the families that were evicted to return. However, the powers of Sheikh Hawary, the Salafi leader remained unshaken and those responsible for the violence were not prosecuted. The signals given implicitly were that citizens can get away with acts of violence against a religious minority, and this seemed to have a ripple effect in the adjoining villages. In May 2012, four months after the incident at $\mathrm{Al}$ Nahdah village, in the nearby village of al Bassra, rumours of an alleged relationship between a Christian man and a Muslim woman developed into a full-scale sectarian incident. In early May 2012, a 20-year-old Coptic Christian who had a small business in selling mobile phones and mobile recharging cards passed by one of his Muslim female neighbours who asked him for a loan of LE20 (less than £2). He gave her the money, but he was seen by a man who was allegedly a member of the Salafi movement. According to the boy's father, this man was responsible for spreading rumours that the Christian man and Muslim woman were in a relationship. He called upon the Muslim residents to congregate at the mosque after evening prayer, after which they attacked the homes and businesses of the Christians living in the village, and one residential home was burnt. Residents of nearby villages later arrived to join in the attacks on the other homes. As in the village of Al Nahdah, Sheikh Sherif el Hawary again presided over a reconciliation session in which it was decided that the young man in question and his family would leave the village for a month. In the reconciliation session, it was also revealed that the rumours regarding the relationship were unfounded. One of the interviewees also affirmed that the young woman had to undergo a medical examination which confirmed her virginity, and thus served as evidence that they were not in a relationship. The man who allegedly belonged to the Salafi movement was never prosecuted for spreading 
rumours, nor were the owners of the houses attacked compensated. Needless to say, the young woman was also not compensated for the loss of reputation and for her exposure to a very humiliating medical examination. Four Christian families voluntarily left the village, fearing for further reprisals.

Interviews were conducted with Christian families living in the village of $\mathrm{Al}$ Bassra in March 2013, ten months after the incident. It was clear from the interviews that social relations were strained. The young man's father said 'relations with our Muslim neighbours are not like before anymore, the relationship now is short, there are no dealings like before. Before there were relations and [a feeling of] love, but after this, it is reduced to hellos and good byes'. The same sentiment was reiterated by other interviewees. This further confirms that informal reconciliation sessions undermine social cohesion, creating the conditions for nonengagement and mistrust. Worse, the political signals given to the broader community can only encourage further violence. First, that those who perpetrate violence against Copts have no reason to fear penalisation because the former are second class citizens. Second, the authority of local Islamist leaders supersedes the powers of the state to administer justice.

\section{Conclusions and key policy messages}

Decentralisation tends to involve a wide range of political, administrative and fiscal policies which can have vastly different designs and approaches. It can be formally pursued by the government or implemented through an informal delegation of powers to local actors. In this article, we have examined two dimensions of the process of devolving political power in Egypt; first, an instance in which local actors sought to assume the powers of choosing their own leader at a local level, and second, the mediation of Islamist forces of reconciliation sessions in lieu of the formerly centrally managed SSI apparatus. Both instances involved an informal process of local actors assuming decision-making powers.

These acts of devolution of power were examined against the backdrop of a highly volatile political context in the aftermath of a revolt that brought an end to Mubarak's 30-year reign and paved the way for the political ascendency to power of the Muslim Brotherhood up until they were ousted from power a year later. It argued that while the revolution did not cause an increase in sectarian tensions between the country's majority and minority religious groups, nevertheless the power configurations that emerged thereafter undermined social cohesion. Hence when local actors assumed power to deal with sectarian matters, the measures and policies reflected unequal relations, rather than redressed them.

Measures which have been popular in decentralisation literature such as local selection of leadership and mediation of conflict through informal justice mechanisms became in such contexts, mechanisms that severely undermined social cohesion.

In the informal reconciliation committee meetings, if one were to define social cohesion in terms of convergence (Marc et al. 2013) or participation with others (Chan et al. 2006), then communal relations may not seem so threatened. However, if one were to consider social cohesion in terms of Norton and De Haan (2012), one would note that (1) there is a disempowerment of minorities, in particular if hidden and invisible forms of power are analysed; (2) cycles of violence are only momentarily disrupted; and (3) the institutions that need strengthening for peaceful management of rapid change such as those associated with rule of law have been weakened at the expense of those institutions that re-enforce power hierarchies on the ground.

Since sectarianism is very deep-seated in Egyptian society, a strong political will at the highest level is the critical factor that would make the most difference here. If such a political will exists, then a number of measures may serve to enhance social cohesion at a local level such as:

1 Develop locally appropriate mechanisms of reporting, documenting and flagging incidents of sectarian conflict. One of the limitations of having to rely on data from the press is that it is often inadequate in exposing underlying power dynamics at work. Also, incidents only come to the surface if they develop into newsworthy items - involving having already evolved into large-scale conflict. It may be worthwhile to examine whether it is possible to institutionalise at a local level mechanisms of reporting on growing tensions that would alert us to where there are threats of possible ruptures emerging in the community. 
2 Protect the independence of the media. In order for a system that flags emerging flashpoints to be effective in eliciting appropriate responses as highlighted previously, the independence of the press and media are essential. The press and media played a central role in exposing the injustices of the outcomes of the reconciliation sessions in all of the incidents mentioned and described previously. While local minorities are sometimes scared that the media's exposure of incidents would aggravate further reprisals against them due to the invisible powers at work, nevertheless, there is no guarantee that if silence is maintained, the situation would not have worsened anyway.

3 Reform the state security apparatus. The retreat of heavy-handed centralised state actors such as the SSI apparatus from managing sectarianism has evidently not brought about social cohesion. What is needed is a different security role, not less security. Local police and other security actors need to manage sectarian conflict differently, and this requires training but also greater accountability.

4 Strengthen rule of law. It is clear that in many of the incidents of sectarian conflict highlighted above, the recourse to formal channels of justice were obstructed. However, the politicisation of the judiciary in dealing with sectarian matters would only serve to undermine prospects of delivering justice. It is critical that even if judicial court rulings are

\section{Notes}

1 Powercube, Understanding Power for Social Change, www.powercube.net/analyse-power (accessed 13 June 2014).

2 Ibid.

3 Ibid.

4 The percentage of different religious groups in Egypt has been hotly contested (Tadros 2013); sometimes anathema to the majority, that they are respected and complied with, in order to send the right signals with regard to sectarian assault.

5 Scrutinise the outcomes of the reconciliation committee meetings as needed. The elimination of reconciliation committee meetings altogether is unlikely to be the solution to fostering social cohesion because locally, it is the informal leaders who wield power, not those working in the local council or in the civil service. In other words, the power configurations are such that those recognised as the elders in the community in addition to religious leaders (both Muslim and Christian) are the ones that have the social legitimacy to make socially binding decisions that people adhere to. However, the reconciliation committees have become mechanisms for the collective punishment of the minorities and for allowing those responsible for inciting violence through the spread of rumours or through inflammatory speeches to evade accountability. The problem is not one of visible power, that is, adequate representation of all parties concerned, but of hidden and invisible power (the influence of religious leaders in citizens' responses to sectarianism, as well as the role of behind-thescenes actors). How to make reconciliation sessions more just will require high-level government policy as well as a strengthened judiciary and improved security.

it is generally regarded as roughly 85-90 per cent Sunni Muslim, about 10 per cent Christian Coptic Orthodox, less than 1 per cent other Christian denominations, mainly Protestant and Catholic, and less than 200,000 Baha'is. Jews account for about 200 members. 5 Al-Wafd, 7 March 2011.

6 Al-Dustour, 11 May 2011. 


\section{References}

Chan, J.; To, H-P. and Chan, E. (2006)

'Reconsidering Social Cohesion: Developing a Definition and an Analytical Framework for Empirical Research', Social Indicators Research 75: 273-302

Dixon, J.; Levine, M.; Reicher, S. and Durrheim, K. (2002) 'Beyond Prejudice: Are Negative Evaluations the Problem and is Getting Us to Like One Another More the Solution?', Behavioural and Brain Sciences 35: 411-66

Gad, E. (2012) 'The Ameriyya [Incident] is Sectarian You Philosophers of Denial', $A l$ Tahrir, 21 February

Kaplan, S. (2009) 'Identity in Fragile States', Development 52.4: 466-72

Marc, A.; Willman, A.; Aslam, G.; Rebosio, M. and Balasuriya, K. (2013) Societal Dynamics and Fragility: Engaging Societies in Responding to Fragile Situations, Open Knowledge Repository, World Bank, https://openknowledge.worldbank.org/ handle/10986/12222 (accessed 13 June 2014)
Norton, A. and De Haan, A. (2012) Social Cohesion: Theoretical Debates and Practical Applications with Respect to Jobs, Background Paper for the World Development Report 2013, Washington DC: World Bank

Oreiby, Ala (2012) 'The Report [Contract] for Expelling Christians from Al Ameriyya', $\mathrm{Al}$ Wafd, 13 February

Shoukry, N. (2009) Lijan al-sulh wa-l-Aqbat, Cairo: Watani Publ.

Tadros, M. (2013) Copts at the Crossroads: The Challenge of Building Inclusive Democracy in Egypt, Cairo: American University in Cairo Press

Tadros, M. (2012a) 'The Pulse of Egypt's Revolt', IDS Bulletin 43.1

Tadros, M. (2012b) The Muslim Brotherhood in Contemporary Egypt: Democracy Redefined or Confined?, London: Routledge

Tranchant, J.P. (2007) Decentralization and Ethnic Conflict: The Role of Empowerment, MPRA Paper 3713, http://mpra.ub.uni-muenchen.de/3713/1/ MPRA_paper_3713.pdf (accessed 13 June 2014) 